\title{
KESANTUNAN BERBAHASA INDONESIA DALAM PEMBELAJARAN DI KELAS X MAN 1 MODEL KOTA BENGKULU
}

\author{
Novia Anggraini, Ngudining Rahayu, dan Bambang Djunaidi \\ Program Studi Pendidikan Bahasa Indonesia \\ Jurusan Pendidikan Bahasa dan Seni \\ FKIP Universitas Bengkulu \\ noviaanggraini0212@gmail.com
}

\begin{abstract}
Abstrak
Penelitian ini bertujuan untuk mendeskripsikan pematuhan dan pelanggaran kesantunan berbahasa Indonesia antara guru dan siswa dalam pembelajaran di kelas X MAN 1 Model Kota Bengkulu berdasarkan prinsip kesantunan Geoffrey Leech. Metode yang digunakan dalam penelitian ini adalah metode deskriptif dengan pendekatan kualitatif. Objek penelitian ini adalah guru dan siswa di kelas X MAN 1 Model Kota Bengkulu. Teknik pengumpulan data dalam penelitian ini yaitu teknik observasi, teknik rekaman dan teknik wawancara. Hasil penelitian ini menunjukkan bahwa dalam proses pembelajaran di kelas $X$ MAN 1 Model Kota Bengkulu terdapat (173) pematuhan tuturan prinsip kesantunan Geoffrey Leech dengan 6 maksim, dan (12) pelanggaran tuturan prinsip kesantunan Geoffrey Leech dengan 4 maksim. Berdasarkan hasil penelitian, maka dapat disimpulkan bahwa kesantunan berbahasa Indonesia di kelas X MAN 1 Model Kota Bengkulu banyak terdapat pematuhan prinsip kesantunan Geoffrey Leech, karena dari (185) data tuturan, terdapat (173) data tuturan pematuhan kesantunan berbahasa Indonesia, dengan kata lain memiliki tingkat pematuhan kesantunan yang tinggi yaitu 93,5\%.
\end{abstract}

Kata kunci: Kesantunan berbahasa, Prinsip Kesantunan Geoffrey Leech, Kelas X MAN 1 Model Kota Bengkulu

\begin{abstract}
This study aims to describe compliance and violation of Indonesian language politeness between teachers and students in learning in class X MAN 1 Model City of Bengkulu based on politeness principles of Geoffrey Leech. The method used in this research is descriptive method with a qualitative approach. The object of this research is teachers and students in class X MAN 1 Model City of Bengkulu. Data collection techniques in this study were observation techniques, recording techniques and interview techniques. The results of this study indicate that in the learning process in class X MAN 1 Model City of Bengkulu there are (173) compliance with Geoffrey Leech's politeness principle utterances with 6 maxims, and (12) violations of politeness principle utterances Geoffrey Leech with 4 maxims. Based on the results of the study, it can be concluded that the politeness of Indonesian language in the class X MAN 1 Model of the City of Bengkulu has a lot of compliance with the
\end{abstract}


politeness principle of Geoffrey Leech, because (185) speech data, there are (173) data in Indonesian politeness, in other words having high politeness compliance rate is $93.5 \%$.

\section{Keyword: Language politeness, politeness principle Geoffrey Leech, Class X MAN 1 Model City of Bengkulu.}

\section{PENDAHULUAN}

Bahasa merupakan alat komunikasi antar manusia dalam kehidupan bermasyarakat berupa bunyi ujaran yang dihasilkan oleh alat ucap manusia. Bahasa juga merupakan alat atau sarana seseorang untuk belajar, bukan hanya sekedar belajar di sekolah namun belajar di lingkungan masyarakat seperti belajar bersosialisasi, belajar memahami etika berbicara dengan seseorang, dan belajar bagaimana menghormati lawan bicara dengan menggunakan bahasa yang santun.

Santun bukan hanya sekedar dilihatkan dengan tingkah laku namun santun juga harus disesuaikan dengan tutur bahasa yang baik. Tuturan akan disebut santun apabila peserta pertuturan tidak terdengar memaksa atau angkuh, tuturan akan santun apabila penutur memperhatikan kata-kata serta bahasa yang akan disampaikan kepada lawan tutur. Menurut Kamus Besar Bahasa Indonesia Edisi Kelima (KBBI V) mengartikan kata santun adalah halus dan baik (budi bahasanya, tingkah lakunya); sabar dan tenang.

Kesantunan merupakan aturan perilaku yang ditetapkan dan disepakati bersama oleh suatu masyarakat tertentu sehingga kesantunan sekaligus menjadi prasyarat yang disepakati oleh perilaku sosial (Yule, 1996: 104).

Hakikatnya kesantunan berbahasa adalah etika kita dalam bersosioalisasi di masyarakat, atau di mana kita berada, dengan penggunaan bahasa dan pemilihan kata yang baik, serta meperhatikan di mana, kapan, dan kepada siapa kita berbicara, karena sesungguhnya bahasa adalah kebudayaan, untuk memahami suatu bahasa kita harus memahami kebudayaan itu sendiri.

Beberapa teori yang membahas tentang kesantunan berbahasa, seperti teori kesantunan Robin Lakoff, yang berbunyi jika tuturan kita ingin terdengar santun di telinga pendengar atau lawan tutur kita ada tiga kaidah yang harus dipatuhi, yaitu formalitas (formality) jangan memaksa atau angkuh (aloof), ketidak tegasan (hesitancy) buatlah sedemikian rupa sehingga lawan tutur dapat menentukan pilihan (option), dan persamaan atau kesekawanan (equality or cameraderie), bertindaklah seolah-olah Anda dan lawan tutur Anda menjadi sama (Chaer, 2010: 46).

Teori kesantunan Bruce Fraser, yang mengatakan bahwa kesantunan adalah properti yang diposisikan dengan tuturan dan di dalam hal ini menurut pendapat si lawan tutur, bahwa si penutur tidak melampaui hak-haknya atau tidak mengingkari dalam memenuhi kewajibannya. Sedangkan penghormatan adalah bagian dari aktivitas yang berfungsi sebagai sarana simbolis untuk menyatakan penghargaan secara reguler (Chaer, 2010: 47).

Maka dalam penelitian ini peneliti memilih menggunakan teori prinsip kesantunan berbahasa Geoffrey Leech. Alasan peneliti menggunakan teori Geoffrey Leech yaitu, karena teori ini lebih lengkap 
dan bahasannya juga lebih mendalam dibandingkan dengan teori-teori sebelumnya, selain itu pada teori Geoffrey Leech ini juga mempunyai enam maksim prinsip kesantunan berbahasa, yang biasanya tanpa sadar sering diterapkan dalam proses pembelajaran.

Prinsip kesantunan Geoffrey Leech (1993) ini meliputi enam maksim sebagai berikut, yaitu Maksim Kearifan (Tact Maxim), Maksim Kedermawanan (Generosity Maxim), Maksim Pujian (Approbation Maxim), Maksim Kerendahan Hati (Modesty Maxim), Maksim Kesepakatan (Agreement Maxim), Maksim Simpati (Sympathy Maxim).

Geoffrey Leech (1993) dalam bukunya menyatakan bahwa kesopanan merupakan satu kajian bagaimana sesuatu ujaran mempunyai makna di dalam sesuatu situasi, di mana terdapat kesediaan pengguna bahasa untuk berkomunikasi, Leech berpendapat bahwa sesuatu keadaan berbahasa itu tergantung pada beberapa faktor relative kekal seperti: umur, status, dan peranan.

Pada penelitian ini, penulis memilih sekolah MAN 1 Model Kota Bengkulu, yang terletak di Jalan Cimanuk Km 6.5/ Jalan Gedang, Gading Cempaka, Kota Bengkulu. MAN 1 Model Kota Bengkulu merupakan sebuah sekolah yang setara dengan SMA. Alasan penulis memilih MAN 1 Model Kota Bengkulu, karena MAN 1 Model Kota Bengkulu terkenal dengan prestasi dibidang agama dan akademik, dengan keunggulan yang dimiliki MAN 1 Model Kota Bengkulu, membuat penulis tertarik untuk meneliti tentang kesantunan berbahasa Indonesia guru dan siswa di kelas X MAN 1 Model Kota Bengkulu pada saat proses pembelajaran berlangsung di dalam kelas.

Penelitian yang relevan membahas tentang kesantunan berbahasa sudah cukup banyak dilakukan, namun yang berkaitan dengan penelitian ini yaitu penelitian yang dilakukan oleh Febrina (2015) dengan skripsinya yang berjudul "Kesantunan Berbahasa Siswa Kelas VII SMP Negeri 7 Kota Bengkulu". Penelitian ini merupakan jenis penelitian deskriptif kualitatif, dalam penelitian Febrina (2015) bertujuan untuk mendeskripsikan kesantunan berbahasa siswa kelas VII SMP Negeri 7 Kota Bengkulu. Hasil penelitian Febrina (2015) menemukan tuturan yang santun dilakukan oleh siswa dengan siswa, guru dan siswa dalam situasi formal maupun non formal dengan menggunakan enam maksim prinsip kesantunan Leech, yaitu maksim kebijaksanaan, maksim kedermawanan, maksim penghargaan, maksim kesederhanaan, maksim permufakatan, dan maksim kesimpatian.

Persamaan dengan penelitian ini terletak pada pengkajian kesantunan berbahasa yang menggunakan prinsip kesantunan Leech dengan berdasarkan enam maksim. Sedangkan perbedaannya dengan penelitian peneliti yaitu peneliti meneliti pematuhan dan pelanggaran prinsip kesantunan berbahasa Indonesia dalam pembelajaran di kelas dengan menggunakan prinsip kesantunan Leech berdasarkan enam maksim, sedangkan penelitian Febrina (2015) hanya mendeskripsikan pematuhan kesantunan berbahasa saja dalam situasi formal maupun non formal. Peneliti berharap melalui penelitian ini, peneliti dapat menemukan temuan yang lain dari apa yang ditemukan oleh Febrina (2015).

Rumusan masalah pada penelitian ini yaitu bagaimanakah pematuhan dan pelanggaran kesantunan berbahasa Indonesia guru dan siswa dalam pembelajaran di kelas X MAN 1 Model Kota Bengkulu berdasarkan prinsip kesantunan Geoffrey Leech yang menggunakan enam maksim? 
Berdasarkan dari hasil uraian di atas, peneliti semakin tertarik untuk meneliti kesantunan berbahasa Indonesia dalam pembelajaran di kelas X MAN 1 Model Kota Bengkulu.

\section{METODE}

Pendekatan penelitian ini adalah menggunakan pendekatan kualitatif dengan metode deskriptif. Objek penelitian ini adalah guru dan siswa di kelas $X$ MAN 1 Model Kota Bengkulu. Peneliti memilih satu orang guru dan empat kelas yaitu, kelas X IPS 2, X IPA 4, X Agama dan X Bahasa yang setiap kelasnya terdiri dari 30 orang siswa khususnya pada mata pelajaran Bahasa Indonesia.

Penelitian ini dilakukan di MAN 1 Model Kota Bengkulu yang terletak di Jalan Cimanuk Km 6.5 / Jalan Gedang, Gading Cempaka, Kota Bengkulu, Bengkulu 38225. Waktu penelitian ini dilaksanakan pada tanggal 08 Mei - 31 Juli 2018.

Data dalam penelitian ini adalah tuturan yang mematuhi kesantuna dan tuturan yang melanggar kesantunan berbahasa Indonesia berdasarkan prinsip kesantunan Geoffrey Leech yang dilakukan oleh guru dan siswa pada saat situasi formal atau saat proses pembelajaran berlangsung di dalam kelas, yaitu di kelas XIPS 2, X IPA 4, $X$ Agama dan X Bahasa MAN 1 Model Kota Bengkulu. Sumber data dalam penelitian ini yaitu seluruh tuturan lisan yang di lakukan oleh guru dan siswa pada saat proses pembelajaran berlangsung dari guru membuka pelajaran, menyampaikan materi, diskusi kelas sampai menutup pelajaran. Instrumen utama dalam penelitian ini yaitu manusia sebagai instrumen, dalam hal ini yaitu peneliti sendiri. Teknik pengumpulan data dalam penelitian ini, yaitu teknik observasi, rekam dan wawancara.
Langkah-langkah analisis data dalam penelitian ini yaitu mentranskripsikan data, mengidentifikasi data, mengklasifikasikan data, menginterpretasikan data, dan menyimpulkan hasil penelitian.

\section{HASIL DAN PEMBAHASAN}

Hasil

Berdasarkan 6 rekaman yang dituturkan oleh Guru dan Siswa pada saat proses pembelajaran berlangsung di dalam kelas X MAN 1 Model Kota Bengkulu, peneliti menemukan adanya pematuhan prinsip kesantunan Geoffrey Leech, dan pelanggaran prinsip kesantunan Geoffrey Leech. 6 rekaman ini diambil dari (4) kelas, yaitu (3) rekaman di kelas $X$ IPS 2, (1) rekaman di kelas X IPA 4, (1) rekaman di kelas X Bahasa, dan (1) rekaman di kelas X Agama.

Setelah dianalisis peneliti menemukan (173) pematuhan tuturan prinsip kesantunan Geoffrey Leech dengan 6 maksim, berikut uraiannya. (65) pematuhan maksim kebijaksanaan yang dituturkan oleh Guru kepada Siswa (58 tuturan) dan Siswa kepada Siswa (7 tuturan); (8) pematuhan maksim kedermawanan yang dituturkan oleh Siswa kepada Siswa; (7) pematuhan maksim penghargaan yang dituturkan oleh Guru kepada Siswa (5 tuturan) dan Siswa kepada Siswa (2 tuturan); (6) pematuhan maksim kesederhanaan yang dituturkan oleh Guru kepada Siswa (2 tuturan) dan Siswa kepada Siswa (4 tuturan); (75) pematuhan maksim permufakatan yang dituturkan oleh Guru kepada Siswa (36 tuturan), Siswa kepada Guru (33 tuturan), dan Siswa kepada Siswa (6 tuturan); (12) pematuhan maksim kesimpatian yang dituturkan oleh Guru kepada Siswa (10 tuturan) dan Siswa kepada Siswa (2 tuturan). Selain itu di dalam pematuhan prinsip kesantunan berbahasa juga terdapat (5) penanda kesantunan berbahasa, yaitu tolong, silakan, ayo, coba, 
dan harap yang digunakan penutur sebagai penghalus tuturan dalam memerintah.

Pada penelitiam ini, peneliti juga menemukan (12) pelanggaran tuturan prinsip kesantunan Geoffrey Leech dengan 4 maksim, yaitu (1) pelanggaran maksim kebijaksanaan yang dituturkan oleh Siswa kepada Siswa; (1) pelanggaran maksim kedermawanan yang dituturkan oleh Siswa kepada Siswa, (8) pelanggaran maksim penghargaan yang dituturkan oleh Guru kepada Siswa (2 tuturan), Siswa kepada Guru (2 tuturan), Siswa kepada Siswa (4 tuturan); (2) pelanggaran maksim permufakatan yang dituturkan oleh Siswa kepada Guru (1 tuturan), dan Siswa kepada Siswa (1 tuturan).

\section{Pembahasan}

\section{Maksim Kebijaksanaan Pematuhan}

Lecch menjelaskan bahwa jika ingin dikatakan mematuhi maksim kebijaksanaa penutur harus membuat kerugian orang lain sekecil mungkin, dan membuat keuntungan orang lain sebesar mungkin (Leech, 1993:206).

Pematuhan maksim kebijaksanaan dalam pembelajaran di kelas X MAN 1 Model Kota Bengkulu sebanyak 65 data tuturan yang dituturkan oleh guru dan siswa pada saat proses pembelajaran di dalam kelas.

\section{Contoh:}

39. Guru : Siapa yang tidak membawa?

40. Siswa 4 (Erinda) : Saya Bu.

41. Guru : Kalian kemana?

42. Siswa 4 (Erinda) : Tidak masuk $\mathrm{Bu}$.

43. Guru : Tidak masuk? Ya sudah terimakasih, diam saja tetap duduk disitu.
Pada tuturan nomor (39) Guru menanyakan kepada Seluruh siswa siapa yang tidak membawa fotokopian, tuturan Guru tersebut merupakan tuturan yang santun karena hal yang wajar jika seorang Guru atau orang yang lebih tua bertanya kepada Siswanya. Pada tuturan (40) Siswa 4 pun menjawab bahwa dia tidak membawa soal fotokopian, dan tuturan Siswa 4 tersebut merupakan tuturan yang santun karena Siswa 4 telah menjawab dan merespon pertanyaan Guru, dan pada tuturannya Siswa 4 menggunakan sapaan Bu yang membuat tuturan Siswa terasa halus didengar dan sapaan tersebut menunjukkan bahwa Siswa sedang berbicara kepada orang yang lebih tua yaitu Guru. Pada tuturan nomor (43) tersebut Guru memberikan toleransinya kepada Siswa 4 yang tidak mempunyai fotokopian dengan masih membiarkan dan membolahkan Siswa 4 untuk tetap ikut dalam pembelajaran, berdasarkan hal tersebut tuturan (43) merupakan tuturan yang santun.

Dapat disimpulkan tuturan antara Guru dan Siswa 4 merupakan tuturan yang santun, dan pada tuturan nomor (43) terdapat tuturan yang mematuhi maksim kebijaksanaan.

\section{Pelanggaran}

Pada maksim kebijaksanaan, Lecch menjelaskan bahwa setiap peserta pertuturan harus meminimalkan kerugian orang lain, atau memaksimalkan keuntungan bagi orang lain (Chaer, 2010: 56). Namun pada pelanggaran maksim kebijaksanaan ini berkebalikan dengan hakikat dari mematuhi maksim kebijaksanaan, yaitu bahwa setiap peserta pertuturan harus memaksimalkan kerugian orang lain, atau meminimalkan keuntungan orang lain.

Pelanggaran maksim kebijaksanaan dalam pembelajaran di kelas X MAN 1 Model 
Kota Bengkulu sebanyak 1 data tuturan yang dituturkan oleh guru dan siswa pada saat proses pembelajaran di dalam kelas.

Contoh:

25. Siswa 5 (Kinanti) : Ko na disajikan dalam bentuk jenis karangan. "Ini disajikan dalam bentuk jenis karangan".

26. Siswa 6 (Sentia) : Kalau idak dapek cari di google. "Kalau tidak dapat cari di google".

27. Siswa 7 (Ira) : Hp kau ajo yo Hp awak buruk. " Hp kamu saja ya Hp saya jelek".

Tuturan tersebut merupakan tuturan yang menggunakan bahasa daerah yaitu bahasa Melayu Bengkulu, bahasa Melayu Bengkulu ini sering dituturkan oleh siswa dengan siswa pada saat proses pembelajaran berlangsung di dalam kelas, hal tersebut dikarenakan faktor kebiasaan siswa saat berbicara dengan teman sebayanya.

Pada tuturan (25) terlihat Siswa 5 sedang menjelaskan jawaban kepada kelompoknya, tuturan (25) ini merupakan tuturan yang santun, karena pada tuturan (25) Siswa 5 telah menunjukkan sikap kebijaksanaannya dengan cara memberi tahu kepada kelompoknya tentang hal yang ia ketahui. Pada tuturan (26) malah terlihat Siswa 6 mengusulkan untuk mencari jawaban di google saja, tuturan (26) ini merupakan tuturan yang santun namun tidak bijaksana, karena pada tuturan (26) Siswa 6 telah mengajak temannya untuk melakukan tindakan yang curang dan akan menimbulkan kerugian bagi mereka, yaitu kerugian yang akan membuat mereka menjadi malas. Pada tuturan (27) terlihat bahwa Siswa 7 setuju dengan pendapat Siswa 6, dan pada tuturan (27) merupakan tuturan yang santun, karena pada tuturan
(27) Siswa 7 telah merendahkan dari apa yang dimilikinya.

Dapat disimpulkan tuturan antara Siswa 5, Siswa 6, dan Siswa 7 merupakan tuturan yang santun. Pada tuturan (26) terdapat tuturan yang melanggar maksim kebijaksanaan. Pelanggaran pada tuturan (26) ini terjadi karena Siswa 6 ingin mencari jawaban yang instan tanpa berfikir secara mandiri.

\section{Maksim Kedermawanan Pematuhan}

Pada maksim kedermawanan atau maksim kemurahan hati ini, para peserta pertuturan diharapkan dapat menghormati orang lain. Penghormatan terhadap orang lain akan terjadi apabila orang dapat mengurangi keuntungan bagi dirinya sendiri dan memaksimalkan keuntungan bagi pihak lain (Rahardi, 2005: 61). Selain itu Leech mengemukakan buatlah keuntungan diri sendiri sekecil mungkin; buatlah kerugian diri sebesar mungkin ( Leech, 1993:209).

Pematuhan maksim kedermawanan dalam pembelajaran di kelas X MAN 1 Model Kota Bengkulu sebanyak (8) data tuturan yang dituturkan oleh guru dan siswa pada saat proses pembelajaran di dalam kelas.

\section{Contoh:}

66. Siswa 10 (Sarah) : Pinjam Tipex?

67. Siswa 11 (Yuliana) : Ini ambik bae "Ini ambil saja."

68. Siswa 10 (Sarah) : Makasih.

Pada saat membahas soal bersama sama, Siswa 10 ingin meminjam tipex kepada Siswa 11 seperti pada tuturan (66) yang dilakukan oleh Siswa 10, tindakan Siswa 10 pada tuturan (66) merupakan tuturan yang santun, karena sebelum mengambil tipex, Siswa 10 terlebih dahulu meminta izin kepada Siswa 11, dan Siswa 11 memberikan tipexnya kepada Siswa 10, tuturan yang disampaikan Siswa 11 dalam meminjamkan 
tipexnya kepada Siswa 10 merupakan tuturan yang menunjukan sifat dermawan dari Siswa 11, mendengar Siswa 11 meminjamkan tipexnya Siswa 10 memerikan rasa terimakasihnya kepada Siswa 11 seperti pada tuturan (68).

Dapat disimpulkan bahwa konteks tuturan yang meminjam tipex yang disampaikan oleh Siswa 10 dan Siswa 11 merupakan tuturan yang santun, dan pada tuturan (67) merupakan tuturan yang mematuhi maksim kedermawanan, dan tuturan (67) oleh Siswa 11 ini menggunakan bahasa daerah yaitu bahasa Melayu Bengkulu pada saat proses pembelajaran berlangsung di dalam kelas, bahasa daerah ini memang sering dituturkan siswa kepada teman sebayanya, hal tersebut dikarenakan faktor kebiasaan dan faktor lingkungan yang selalu menggunakan bahasa Melayu Bengkulu.

\section{Pelanggaran}

Pada maksim kedermawanan Leech mengemukakan, buatlah keuntungan diri sendiri sekecil mungkin; buatlah kerugian diri sebesar mungkin ( Leech, 1993:209). Jika pematuhan maksim kedermawanan berbunyi seperti itu, maka pelanggaran maksim kedermawanan berkebalikan dengan hakikatnya, yaitu peserta pertuturan memaksimalkan atau memperbanyak keuntungan bagi diri sendiri dan meminimalkan keuntungan bagi pihak lain.

Pelanggaran maksim kedermawanan dalam pembelajaran di kelas X MAN 1 Model Kota Bengkulu sebanyak (1) data tuturan yang dituturkan oleh guru dan siswa pada saat proses pembelajaran di dalam kelas.

\section{Contoh:}

4. Guru : Sampahnya itu dibuang

5. Siswa 1 (Doan) : Buanglah Du !

6. Siswa 2 (Pandu) : Iyo. "Iya."
Sebelum memulai pelajaran pada tuturan nomor (4) Guru menyuruh Siswa membuang sampah yang berserakan di depan meja Guru, tuturan Guru tersebut merupakan tuturan yang santun karena yang memerintah untuk membuang sampah adalah Guru kepada Siswa jadi hal yang wajar jika Guru memerintah Siswa, dan juga perintah Guru tersebut tidak tertuju kepada satu Siswa melainkan semua Siswa X IPS 2. Pada tuturan nomor (5) Siswa 1 melemparkan perintah Guru secara langsung kepada Siswa 2 yang menunjukkan bahwa Siswa 1 tidak ingin dibebankan dan meimpahkan beban tersebut kepada Siswa 2 dengan hal tersebut tuturan nomor (5) merupakan tuturan yang kurang santun, dapat dilihat pada tuturan nomor (6) Siswa 2 membantu Guru sesuai dengan apa yang diperintahkan Siswa 1, dan tuturan nomor (6) merupakan tuturan yang santun karena Siswa 2 telah memaksimalkan kerugian (beban) untuk dirinya.

Dapat disimpulkan bahwa pada tuturan antara Guru, Siswa 1 dan Siswa 2, terdapat tuturan yang melanggar maksim kedermawanan yaitu pada tuturan nomor (5).

\section{Maksim Penghargaan \\ Pematuhan}

Menurut Rahardi (2005:62) dalam maksim penghargaan dijelaskan bahwa seseorang akan dapat dianggap santun apabila dalam bertutur selalu berusaha memberikan penghargaan kepada pihak lain. Dengan maksim ini, diharapkan agar para peserta pertuturan tidak saling mengejek, saling mencaci, atau saling merendahkan pihak lain.

Pematuhan maksim penghargaan dalam pembelajaran di kelas X MAN 1 Model Kota Bengkulu sebanyak (7) data tuturan 
yang dituturkan oleh guru dan siswa pada saat proses pembelajaran di dalam kelas.

\section{Contoh:}

56. Siswa 2 (Pandu) : Rapi tulisan kau Piq. " Tulisan kamu rapi Piq."

57. Siswa 12 (Taupiq) : Aih pacak nian kau ko "Ah kamu bisa saja."

Tuturan tersebut merupakan tuturan yang menggunakan bahasa daerah yaitu bahasa Melayu Bengkulu, bahasa Melayu Bengkulu ini sering dituturkan oleh siswa dengan siswa pada saat proses pembelajaran, hal tersebut dikarenakan faktor kebiasaan siswa saat berbicara dengan teman sebayanya.

Pada tuturan (56) terlihat Siswa 2 sedang melihat tulisan dari Siswa 12, dan setelah melihat tulisan Siswa 12 Siswa 2 langsung melontarkan pujiannya kepada Siswa 12, pujian yang diberikan Siswa 2 kepada Siswa 12 ini merupakan tuuran yang santun dan juga merupakan bentuk kekaguman Siswa 2 terhadap tulisan Siswa 12, mendengar pujian yang diberikan Siswa 2 Siswa 12 pun melontarkan tuturan yang santun dan tidak meninggikan hatinya seperti tuturan (57).

Dapat disimpulkan bahwa tuturan antara Siswa 2 dan Siswa 12 adalah tuturan yang santun karena pada tuturan (56) terdapat yang mematuhi maksim penghargaan.

\section{Pelanggaran}

Menurut Rahardi (2005:62) dalam maksim penghargaan dijelaskan bahwa seseorang akan dapat dianggap santun apabila dalam bertutur selalu berusaha memberikan penghargaan kepada pihak lain. Dengan maksim ini, diharapkan agar para peserta pertuturan tidak saling mengejek, saling mencaci, atau saling merendahkan pihak lain. Jika pematuhan penghargaan berbunyi seperti hal tersebut, maka bunyi dari pelanggaran maksim penghargaan ini, yaitu tidak memberikan penghargaan pada pihak lain. Para peserta pertuturan saling mengejek, saling mencaci, atau saling merendahkan pihak yang lain. Peserta tutur yang sering mengejek peserta tutur lain di dalam kegiatan bertutur akan dikatakan sebagai orang yang tidak sopan.

Pelanggaran maksim penghargaan dalam pembelajaran di kelas X MAN 1 Model Kota Bengkulu sebanyak (8) data tuturan yang dituturkan oleh guru dan siswa pada saat proses pembelajaran di dalam kelas.

\section{Contoh:}

164. Guru : Lanjut Apip!

165. Siswa 16 (Apip): A Bu?

166. Guru : Baca teks soalnya Pip!

167. Siswa 1 (Doan) : Woi baco soal tu, alang ke didik kau Pip. "Woi baca tu, bodoh kamu Pip."

168. Guru : : Teksnya dibaca dulu Pip.

169. Siswa 16 (Apip): Iya Bu.

170. Siswa 16 (Apip) : : (Membaca teks soal) jawabannya $\mathrm{ABu}$.

171. Guru : Iya tidak sulit itu, dia menceritakan W.S Rendra pengarang puisi paling bagus, na sekarang dia sudah meninggal, tidak ada lagi.

Pada saat memulai membahasa soal pertama di bab delapan, Guru langsung menyuruh Siswa 16 untuk membahas soal pertama seperti pada tuturan (164), namun pada tuturan (165) Siswa 16 hanya membacakan jawabannya saja, mendengar 
hal tersebut Siswa 1 langsung melontarkan tuturan yang kasar seperti pada tuturan (167), tuturan (167) yang dilakukan Siswa 1 tentu membuat Siswa 16 tersinggung, alasan Siswa 1 melontarkan tuturan yang kasar kepada Siswa 16 itu dikarenakan Siswa 1 kesal karena Siswa 16 tidak menyimak apa yang sudah dilakukan oleh teman yang sebelumnya sudah mendapat giliran menjawab soal, tanpa menanggapi tuturan Siswa 1 Siswa 16 langsung menuruti perintah Guru untuk membaca dan menjawab soal seperti pada tuturan (168) dan (169), dan jawaban Siswa 16 ternyata benar hal tersebut dapat dilihat dari tuturan (171) yang dilakukan oleh Guru.

Dapat disimpulkan bahwa tuturan (167) merupakan tuturan yang kurang santun dan melanggar maksim penghargaan.

\section{Maksim Kesederhanaan}

\section{Pematuhan}

Pada maksim ini Leech 1993 mengungkapkan tuturan akan santun jika peserta pertuturan mengurangi pujiannya pada dirinya sendiri, dan menambah cacian pada diri sendiri.

Pematuhan maksim kesederhanaan dalam pembelajaran di kelas X MAN 1 Model Kota Bengkulu sebanyak (6) data tuturan yang dituturkan oleh guru dan siswa pada saat proses pembelajaran di dalam kelas.

\section{Contoh :}

210. Siswa 25 (Agam) : Boleh nengok tulisan kau tadi? "Boleh lihat soal yang kamu tulis tadi?"

211. Siswa 26 (Rangga) : Tulisan awak buruk, kelak kau dak pacak mbaconyo. "Tulisan saya jelek, nanti kamu tidak bisa membacanya."

212. Siswa 25 (Agam) : Bisa.

213. Siswa 26 (Rangga) : Pinjamlah.

214. Siswa 25 (Agam) : Ambo bawa balik yo. "Saya bawa pulang ya."

215. Siswa 26 (Rangga) : lyo tapi jangan lamo ambo ndak bue. "Iya tapi jangan lama saya mau mengerjakan."

216. Siswa 25 (Agam) : Sip.

Tuturan tersebut merupakan tuturan yang menggunakan bahasa daerah yaitu bahasa Melayu Bengkulu, bahasa Melayu Bengkulu ini sering dituturkan oleh siswa dengan siswa pada saat proses pembelajaran, hal tersebut dikarenakan faktor kebiasaan siswa saat berbicara dengan teman sebayanya.

Tuturan (210) terlihat bahwa Siswa 25 ingin meminjam buku tulis Siswa 26, tindakan Siswa 25 pada tuturan (204) merupakan tindakan yang baik, karena sebelum mengambil buku tulis Siswa 26 Siswa 25 terlebih dahulu meminta izin kepada Siswa 26, dan Siswa 26 seperti pada tuturan (211) secara tidak langsung menolak ingin meminjamkan bukunya kepada Siswa 25, penolakan Siswa 26 dilakukannya dengan cara menghina tulisannya sendiri seperti pada tuturan (211), dan Siswa 25 tetap ingin meminjam tulis Siswa 26 seperti pada tuturan (212), alasan Siswa 26 menuturkan tuturan (211), karena Siswa 26 ingin membuat PR pada saat sepulang sekolah dan pada tuturan (213) merasa tidak enak hati Siswa 26 akhirnya pun meminjamkan buku tulisannya kepada Siswa 25, pada tuturan (214) Siswa 25 ingin membawa pulang buku tulisan Siswa 26, dan pada tuturan (216) Siswa 26 pun mengizinkan Siswa 25 untuk 
membawa bukunya pulang dengan satu syarat jangan terlalu lama karena Siswa 26 ingin mengerjakan tugas yang diberikan oleh Guru.

Dapat disimpulkan bahwa tuturan yang disampaikan Siswa 25 dan Siswa 26 merupakan tuturan yang santun, dan pada tuturan (211) merupakan tuturan yang mematuhi maksim kesederhanaan.

\section{Pelanggaran}

Pada maksim kesederhanaan Leech 1993 mengungkapkan tuturan akan santun jika peserta pertuturan mengurangi pujiannya pada dirinya sendiri, dan menambah cacian pada diri sendiri. Pelanggaran ini berkebalikan dari hakikat maksim kesederhanaan yaitu peserta tutur tidak dapat bersikap rendah hati dengan cara menambah pujian terhadap dirinya sendiri.

Pada penelitian ini, peneliti tidak menemukan adanya tuturan yang melanggar maksim kesederhanaan pada saat proses pembelajaran Bahasa Indonesia di dalam kelas.

\section{Maksim Permufakatan}

\section{Pematuhan}

Leech 1993 mengatakan bahwa penutur harus mengurangi ketidak sesuaian antara diri sendiri dengan orang lain, dan tingkatkan persesuaian antara diri sendiri dengan orang lain. Selain itu Rahardi (2005:64) menjelaskan bahwa di dalam maksim ini ditekankan agar para peserta tutur dapat saling membina kecocokan atau kemufakatan di dalam kegiatan bertutur.

Pematuhan maksim permufakatan dalam pembelajaran di kelas X MAN 1 Model Kota Bengkulu sebanyak (75) data tuturan yang dituturkan oleh guru dan siswa pada saat proses pembelajaran di dalam kelas.

Contoh :
17. Guru : Mau kelompok atau sendiri?

18. Siswa : Sendiri (serentak).

19. Guru : Iya sendiri.

Pada tuturan (17) Guru sedang memberikan pilihan kepada Siswa yang bermasalah untuk menulis surat pernyataan secara kelompok atau sendiri, dengan begitu tuturan (17) merupakan tuturan yang santun karena pada tuturan tersebut Guru tidak memberikan beban kepada Siswa, dan pada tuturan (18) Siswa telah memberikan pilihannya kepada Guru, dan pada tuturan (19) Guru pun menyetujui dari pilihan Siswa tersebut.

Dapat disimpulkan bahwa tuturan Guru dan Siswa adalah tuturan yang santun, dan pada tuturan (18) dan (19) merupakan tuturan yang mematuhi maksim permufakatan.

\section{Pelanggaran}

Leech 1993 mengatakan bahwa penutur harus mengurangi ketidak sesuaian antara diri sendiri dengan orang lain, dan tingkatkan persesuaian antara diri sendiri dengan orang lain. Pelanggaran ini berkebalikan dari hakikat maksim permufakatan yaitu penutur dan lawan tutur meminimalkan kesetujuan di antara mereka, dan memaksimalkan ketidak setujuan di antara mereka.

Pelanggaran maksim permufakatan dalam pembelajaran di kelas X MAN 1 Model Kota Bengkulu sebanyak (2) data tuturan yang dituturkan oleh guru dan siswa pada saat proses pembelajaran di dalam kelas.

\section{Contoh :}

156. Siswa 1 (Doan) :

Assalamualaikum.

157. Guru : Wa'alaikum salam.

158. Guru : Dimana kamu beli pena?

159. Siswa 1 (Doan) : Kepahiyang. 


\begin{tabular}{|c|c|}
\hline 60. Guru & $\begin{array}{l}: \quad \text { Dekat } \\
\text { Kepahiyang. }\end{array}$ \\
\hline 161. Siswa 1 (Doan) & : Tais Tais. \\
\hline 162. Guru & $\begin{array}{l}\text { : Sudah dibilar } \\
\text { kalau mau keluar iz } \\
\text { jangan lama kenap } \\
\text { kamu lama? }\end{array}$ \\
\hline 63. Siswa 1 (Doan) & 1) : Idak Bu. \\
\hline & Tidak Bu”. \\
\hline 64. Guru & $\begin{array}{l}\text { : Dengar yang lain, } \\
\text { Ibu memberi izin } \\
\text { kalian keluar beli } \\
\text { pena itu bukan } \\
\text { menyuruh kalian } \\
\text { makan di kantin tapi } \\
\text { biar kalian bisa nulis, } \\
\text { bisa ikut belajar, ini } \\
\text { malah makan di } \\
\text { kantin, lbu tidak } \\
\text { percaya lagi sama } \\
\text { kalian kalau mau izin } \\
\text { beli pena. }\end{array}$ \\
\hline
\end{tabular}

Saat ingin membahas soal pertama, tiba-tiba Siswa 1 masuk dan mengucapkan salam kepada kelas X IPS 2 seperti tuturan (165), pada tuturan (157) Guru membalas salam yang diberikan Siswa 1 . Setelah Siswa 1 duduk di kursinya pada tuturan (158) secara tidak langsung Guru menanyakan kepada Siswa 1 kenapa lama sekali izin membeli pena, namun jawaban yang diberikan Siswa 1 kurang menghargai Guru seperti pada kalimat (159). Pada tuturan (162) Guru bertanya kepada Siswa 1 yang menampakan bahwa Siswa 1 telah melanggar perjanjian yang telah dibuat saat Siswa 1 ingin meminta izin untuk membeli pena di awal pembelajaran, namun perjanjian itu dilanggar oleh Siswa 1, dan pada tuturan (163) Siswa 1 hanya menjawab tidak tanpa memberikan penjelasan dan jawaban Siswa 1 tersebut menampakkan bahwa Siswa 1 memang telah melanggar perjanjian yang dibuatnya dengan Guru.

Dapat disimpulkan bahwa tuturan Siswa 1 kepada Guru merupakan tuturan yang kurang santun, karena Siswa 1 tidak menampakan rasa hormatnya saat berbicara kepada Guru orang yang lebih tua, dan tuturan (163) merupakan tuturan yang menunjukkan bahwa adanya pelanggaran maksim permufakatan.

\section{Maksim Kesimpatian}

Pematuhan

Maksim kesimpatian mengharuskan semua peserta pertuturan untuk memaksimalkan rasa simpati, dan meminimalkan rasa antipati kepada lawan tuturnya. Bila lawan tutur memperoleh keberuntungan atau kebahagiaan penutur wajib memberikan ucapan selamat. Jika lawan tutur mendapat kesulitan atau musibah penutur sudah sepantasnya menyampaikan rasa duka atau bela sungkawa sebagai tanda kesimpatian (Chaer, 2010: 61).

Pematuhan maksim kesimpatian dalam pembelajaran di kelas X MAN 1 Model Kota Bengkulu sebanyak (12) data tuturan yang dituturkan oleh guru dan siswa pada saat proses pembelajaran di dalam kelas.

\section{Contoh :}

32. Guru : Untuk Agam dan Arpian, tolong kalian jangan lagi bergaul dengan orang-orang Ipuh itu, lbu tahu kondisi geng Ipuh itu tertangkap di kafe. Boleh berteman dengan mereka tapi sebatas kekeluargaan saja, Ibu sedih jika kalian seperti ini, prihatin sekali Ibu, 
banyak sekali ulahnya kalian ini, kalau orang tua kalian tahu kalian banyak tingkah seperti ini sudah pasti mereka sangat sedih.

33. Guru : Sanak kamu beduo ni? "Keluarga kalian berdua?"

34. Siswa 7 (Arpian) : lyo Bu. "Iya Bu".

Pada tuturan (32) Guru memberi nasehat kepada dua orang Siswa yang juga bermasalah pada mata pelajaran Akidah Akhlak yang bergabung dengan suatu kelompok dari daerah mereka, nasehat yang diberikan Guru kepada kedua Siswa tersebut merupakan bentuk perhatian dan kepedulian Guru kepada Siswanya, dengan nasehat tersebut membuat tuturan yang disampaikan Guru menjadi santun dan bisa diterima oleh kedua Siswanya. Pada tuturan (32) juga terdapat penanda kesantunan tolong dan tuturan tersebut terlihat juga Guru sedang memberikan rasa simpatinya kepada orang tua kedua Siswa tersebut. Pada tuturan (33) Guru bertanya apakah kedua Siswa tersebut saudara, tuturan yang digunakan Guru saat bertanya kepada siswanya menggunakan bahasa daerah, hal tersebut dikarenakan Guru menunjukkan rasa keakraban dengan siswanya.

Pada tuturan nomor (43) Siswa 7 pun mengiyakan yang bermaksud memberi tahu Guru bahwa kedua Siswa tersebut masih bersaudara, dan tuturan yang disampaikan Siswa 7 kepada Guru juga santun, karena pada tuturan tersebut ada sapaan $\mathbf{B u}$, sapaan Bu yang digunakan Siswa 7 ini menunjukkan bahwa Siswa 7 sedang berbicara dengan orang yang lebih tua, dan dengan sapaan tersebut tuturan Siswa 7 terdengar halus dan sopan.
Dapat disimpulkan bahwa tuturan antara Guru dan Siswa adalah tuturan yang santun, dan pada tuturan (32) merupakan tuturan yang mematuhi maksim kesimpatian.

\section{Pelanggaran}

Maksim kesimpatian mengharuskan semua peserta pertuturan untuk memaksimalkan rasa simpati, dan meminimalkan rasa antipati kepada lawan tuturnya. Bila lawan tutur memperoleh keberuntungan atau kebahagiaan penutur wajib memberikan ucapan selamat. Namun pelanggaran ini berkebalikan dari hakikat maksim kesimpatian, yaitu peserta pertuturan tidak memaksimalkan rasa simpati, dan tidak meminimalkan rasa antipasti kepada lawan tuturnya.

Pada penelitian ini, peneliti tidak menemukan adanya tuturan yang melanggar maksim kesimpatian pada saat proses pembelajaran Bahasa Indonesia di dalam kelas.

\section{PENUTUP}

\section{Kesimpulan}

Berdasarkan hasil penelitian, maka dapat disimpulkan bahwa kesantunan berbahasa Indonesia di kelas X MAN 1 Model Kota Bengkulu banyak terdapat pematuhan prinsip kesantunan Geoffrey Leech, karena dari (185) data tuturan, terdapat (173) data tuturan pematuhan kesantunan berbahasa Indonesia, atau dengan kata lain memiliki tingkat pematuhan kesantunan yang tinggi yaitu $93,5 \%$, dan terdapat (12) data tuturan pelanggaran kesantunan berbahasa Indonesia atau dengan kata lain memiliki tingkat pelanggaran kesantunan yang rendah yaitu $6,5 \%$.

\section{Saran}


Berdasarkan dari hasil penelitian yang telah dilakukan, penulis menyadari bahwa pada penelitian ini masih kurang sempurna, hal tersebut dikarenakan pada saat mengidentifikasi data, penulis tidak menemukan pelanggaran dengan enam maksim yang lengkap. Maka dari itu untuk penelitian selanjutnya diharapkan bisa menemukan pelanggaran tuturan prinsip kesantunan leech dengan enam maksim yang lengkap yang tidak penulis temukan, yaitu pelanggaran maksim kesederhanaan, dan pelanggaran maksim kesimpatian.

Bagi peneliti selanjutnya, diharapkan agar bisa meneliti bukan hanya pada konteks formal atau saat proses pembelajaran saja, namun juga pada konteks nonformal atau di luar pembelajaran baik guru dan guru, guru dan siswa, siswa dan siswa, dengan menggunakan lima skala kesantunan Leech hal tersebut dikarenakan pada penelitianpenelitian terdahulu yang membahas tentang kesantunan berbahasa belum ada menggunakan teori skala kesantunan Leech sebagai alat pembedah atau alat untuk menganalisis tentang kesantunan, hal tersebut agar pada penelitian selanjutnya, bisa menemukan pematuhan dan pelanggaran kesantunan berbahasa Indonesia yang lebih bervariasi.

\section{DAFTAR PUSTAKA}

Chaer, Abdul. 2010. Kesantunan Berbahasa. Jakarta: Rineka Cipta.

Febrina, Weni. 2015. Kesantunan Berbahasa Siswa Kelas VII SMPN 7 Kota Bengkulu. Bengkulu: Universitas Bengkulu. Skripsi.

Kementrian Pendidikan dan Kebudayaan Republik Indonesia. 2016. Kamus Besar Bahasa Indonesia Edisi Kelima (KBBI V): Aplikasi Luring Resmi Badan Pengembangan dan Pembinaan Bahasa.

Leech, Geoffrey. 1993. Prinsip-prinsip Pragmatik. Jakarta: Universitas Indonesia Press.

Rahardi, Kunjana. 2010. Pragmatik Kesantunan Imperatif Bahasa Indonesia. Jakarta: Erlangga.

Yule, George. 2006. Pragmatik. Yogyakarta: Pustaka Pelajar. 